\title{
DIMENSI PERILAKU \\ PROMOSI KESEHATAN REMAJA \\ BERDASARKAN PERBEDAAN JENIS KELAMIN
}

\author{
Elok Halimatus Sakdiyah \\ Fakultas Psikologi \\ Universitas Islam Negeri (UIN) Maulana Malik Ibrahim Malang \\ Jl. Gajayana 50 Malang Telp. 0341-558916
}

\begin{abstract}
Abstrak - Penelitian ini bertujuan menguji dimensi-dimensi perilaku promosi kesehatan remaja ditinjau dari perbedaan jenis kelamin. Subjek penelitian adalah remaja SMA yang berjumlah 214 siswa dari kota Malang. Pengambilan data dilakukan dengan menggunakan angket dan dianalisis menggunakan uji t dibantu dengan program SPSS 17.00 for windows. Hasil penelitian menunjukkan diskriminasi berdasar jenis kelamin pada dimensi-dimensi perilaku promosi kesehatan hanya ditemukan pada perilaku nutrisi dan perilaku olahraga, dimana remaja putra menunjukkan tingkat yang lebih tinggi dibandingkan remaja putri. Pada dimensi perilaku promosi kesehatan lainnya, yakni dukungan sosial, penghargaan terhadap hidup, perilaku yang bertanggung jawab pada kesehatan, dan managemen emosi, tidak ditemukan adanya diskriminasi berdasar jenis kelamin.
\end{abstract}

Kata Kunci : Perilaku promosi kesehatan, jenis kelamin

PSIKOISLAMIKA. Jurnal Psikologi Islam (JPI) copyright @ 2013 Laboratorium Penelitian, Kajian Psikologi Islam dan Penerbitan. Volume 10. Nomor 1, Tahun 2013

\section{PENDAHULUAN}

Masa remaja merupakan periode perkembangan yang penting dalam kaitannya dengan keadaan sehat dan keadaan tidak sehat. Banyak perilaku sehat (misalnya; diet, dan olahraga) serta perilaku tidak sehat (merokok, minum alkohol, napza, seks bebas) berkembang selama masa remaja. Konsekuensi jangka panjang kesehatan dan kesejahteraan remaja bergantung pada tingkat dan tipe keterlibatan remaja dalam kesehatan, baik perilaku sehat maupun perilaku tidak sehat (Lerner \& Galambos, 1998).

Di Indonesia penelitian tentang perilaku tidak sehat remaja telah banyak dilakukan dengan harapan dapat mengurangi penyebaran perilaku tidak sehat remaja. Apalagi data perilaku tidak sehat, mulai dari perilaku merokok, minum minuman beralkohol, narkotika dan sejenis, seks bebas, dan aborsi yang dilakukan remaja menunjukkan peningkatan jumlah cukup signifikan dari tahun ke tahun, semakin menimbulkan keprihatinan banyak kalangan (Chasanah, 2010; Hatmadji \& Rochani, 1993; Ford. dkk, 1997; Hasmi, 2001; PKPBI, 2005; Sakdiyah 2011; Synovate Research, 2005; Widianti, 2007).

Selama ini sebagian besar penelitian kesehatan, baik kesehatan fisik dan mental remaja secara eksklusif memfokuskan pada bentuk penyakit dan psikopatologi, serta lebih banyak dikaitkan dengan gangguan internal, misalnya, kecemasan, depresi, serta gangguan eksternal misalnya, perilaku minum alkohol, napza, perilaku agresif dalam berkendara, dan lain sebagainya (Shaffer Hudskin, 2011). Di Amerika, penelitian dalam skala besar lebih sering menguji perilaku tidak sehat (misalnya, perilaku merokok, penggunaan narkoba, perilaku sedentary dan lain-lain) dibandingkan perilaku yang meningkatkan kesehatan remaja (Hendricks \& Hendriks, 2005). Hal yang sama juga terjadi di Indonesia, dimana penelitian perilaku kesehatan yang dilakukan, baik oleh institusi resmi pemerintah, 
kalangan independen maupun akademisi lebih sering difokuskan pada jenis-jenis perilaku tidak sehat tertentu dibandingkan eksplorasi terhadap perilaku yang meningkatkan kesehatan remaja.

Hasil penelitian tentang perilaku berisiko terhadap kesehatan atau perilaku tidak sehat biasanya digunakan untuk mendisain program mengatasi perilaku tidak sehat, namun ternyata hal tersebut menunjukkan keterbatasan dampak jangka panjang pada kesehatan remaja (Eaton, et al., 2005). Oleh karena itu, dewasa ini fokus penelitian bergeser pada perilaku sehat bukan hanya terfokus pada perilaku tidak sehat, karena penelitian tentang perilaku sehat terutama perilaku sehat multidimensi dianggap memberikan optimisme yang lebih besar untuk meningkatkan status kesehatan kehidupan remaja (Keyes, 2002). Para peneliti meyakini bahwa tidak adanya penyakit baik fisik atau mental tidak cukup untuk menyimpulkan bahwa remaja berada dalam keadaan baik atau sehat. Dengan menggunakan paradigma promotif dan preventif kesehatan, remaja yang berada dalam keadaan baik adalah mereka yang puas dengan kehidupan mereka, sehat serta kuat pada banyak domain kehidupan (Keyes, 2002).

Memahami perilaku sehat secara holistik memungkinkan para profesional dan akademisi untuk meneliti kesehatan dan perilaku remaja sebagai serangkaian faktor yang terintegrasi bukan hanya potongan yang terisolasi. Data-data tersebut dapat digunakan untuk menginformasikan program-program kesehatan dan strategi pencegahan perilaku tidak sehat bagi remaja yang mungkin dalam perkembangan selanjutnya rentan terlibat dalam perilaku tidak sehat (misal, remaja yang tidak menunjukkan gejalagejala gangguan fisik atau penyakit mental, tetapi memiliki kepuasan atau kebahagiaan hidup yang rendah, dan perilaku sehat yang rendah, misalnya partisipasi yang rendah dalam olahraga dan diet yang tidak sehat (Shafer-Hudskin, 2011). Dengan menetiti komponen yang memengaruhi perilaku sehat remaja, praktisi dan peneliti dapat memahami dan mengatasi masalah kesehatan remaja dengan lebih baik melalui model pencegahan. Perilaku sehat yang dikonseptualisasikan dalam penelitian ini, merupakan perilaku sehat multidimensi yang mengacu pada perilaku/aktivitas yang ditujukan untuk meningkatkan kesejahteraan dan potensi kesehatan individu (Pender, et al., 2005).

Pada penelitian ini, peneliti meneliti dimensi dari perilaku yang mempromosikan kesehatan remaja ditinjau dari jenis dalam konteks budaya
Indonesia pada remaja, yang selanjutnya dapat dijadikan sebagai informasi program prevensi dan promosi kesehatan remaja. Para peneliti menekankan perlunya mempromosikan kebiasaan sehat pada remaja karena pada masa ini, merupakan periode inisiasi atau awal mula remaja merumuskan sendiri kebiasaan berperilaku sehat yang akan berlanjut menjadi kebiasaan di usia selanjutnya (Diener, 2000). Dengan demikian fokus mempromosikan kebiasaan yang sehat pada usia remaja menjadi hal penting karena dapat berefek jangka panjang terhadap kesehatan fisik maupun mental remaja. Adapun rumusan masalah dalam penelitian ini adalah apakah ada perbedaan dimensi perilaku mempromosikan kesehatan ditinjau dari perbedaan jenis kelamin pada remaja siswa menengah atas di kota Malang.

\section{KERANGKA KERJA TEORI}

Pengertian Perilaku Promosi Kesehatan dan Dimensinya

Sehat merupakan sebuah keadaan yang tidak hanya terbebas dari penyakit akan tetapi juga meliputi seluruh aspek kehidupan manusia yang meliputi aspek fisik, emosi, sosial dan spiritual. Menurut WHO (Potter \& Perry, 2005) sehat dapat diartikan sebagai suatu keadaan yang sempurna baik secara fisik, mental dan sosial, serta bebas dari penyakit, cacat dan kelemahan. Definisi WHO tentang sehat mempunyai karakteristik berikut yang dapat meningkatkan konsep sehat yang positif (Edelman \& Mandle. 1994):

1. Memperhatikan individu sebagai sebuah sistem yang menyeluruh.

2. Memandang sehat dengan mengidentifikasi lingkungan internal dan eksternal.

3. Penghargaan terhadap pentingnya peran individu dalam hidup.

Dalam UU Kesehatan No.23,1992, kesehatan didefinisikan secara lebih kompleks sebagai keadaan sejahtera dari badan, jiwa, dan sosial yang memungkinkan individu hidup produktif secara sosial dan ekonomi (http:/ / www. affaveti.org/wp- content/ uploads/2010/09/uu23_1992_ind.pdf). Tidak hanya terbebas dari gangguan fisik, mental dan sosial, tetapi kesehatan dipandang sebagai alat atau sarana untuk hidup secara produktif. Dengan demikian upaya kesehatan yang dilakukan, diarahkan pada upaya yang dapat mengarahkan individu mencapai kesehatan agar dapat hidup produktif. Keadaan ini 
sering disebut sebagai kesehatan prima (Maulana, 2009). Konsep dasar dari kesehatan prima meliputi tanggung jawab individu, pencapaian tujuan, dinamis, pertumbuhan proses, dan pengambilan keputusan sehari-hari dalam hal nutrisi, pengelolaan stres, olahraga fisik, pelaksanaan upaya pencegahan, kesehatan emosi dan aspek lain dalam kesehatan individu. Sebagaimana yang disampaikan oleh Travis \& Ryan (Maulana, 2009) yang menyatakan sehat prima adalah kemampuan individu untuk memilih jalan hidupnya, mampu berproses, menggunakan energi secara efisien, terjadinya integrasi yang baik antara tubuh, akal dan perasaan, serta dapat menerima dan mencintai apa yang dimiliki.

Kozier et al. (1997) mengungkapkan optimasi kesehatan prima manusia harus memenuhi lima dimensi, yakni dimensi fisik, sosial, emosi, entelektual dan spiritual. Dimensi fisik, mengacu pada kemampuan mempraktekkan gaya hidup yang positif. Dimensi fisik meliputi kemampuan menyelesaikan tugas sehari-hari, pencapaian kebugaran fisik, menjaga nutrisi, bebas dari penggunaan obat-obatan, alkohol dan rokok. Dimensi sosial adalah kemampuan berinteraksi secara baik dengan lingkungan, menjaga dan mengembangkan keakraban individu, menghargai serta toleran terhadap setiap pendapat dan kepercayaan yang berbeda. Dimensi emosi , merujuk pada kemampuan mengelola stres dan mengekspresikan emosinya dengan cara yang dapat diterima oleh orang lain. Kesehatan emosi juga mencakup kemampuan untuk bertanggung jawab, menerima, dan menyampaikan perasaanya, serta dapat menerima keterbatasan orang lain. Dimensi intelektual adalah kemampuan belajar dan menggunakan informasi secara efektif antar personal, keluarga, dan pengembangan karir. Kesehatan intelektual meliputi usaha untuk secara terus-menerus tumbuh dan belajar beradaptasi secara efektif dengan perubahan yang terjadi. Dimensi spiritual mengacu pada kepercayaan terhadap beberapa kekuatan (seperti alam, ilmu pengetahuan, agama, dan bentuk kekuatan (ain) yang diperlukan individu dalam mengisi kehidupannya. Setiap individu memiliki nilai, moral, dan etika yang dianut. Dimensi-dimensi yang menjadi determinan kesehatan prima tersebut dapat digambarkan sebagai berikut:

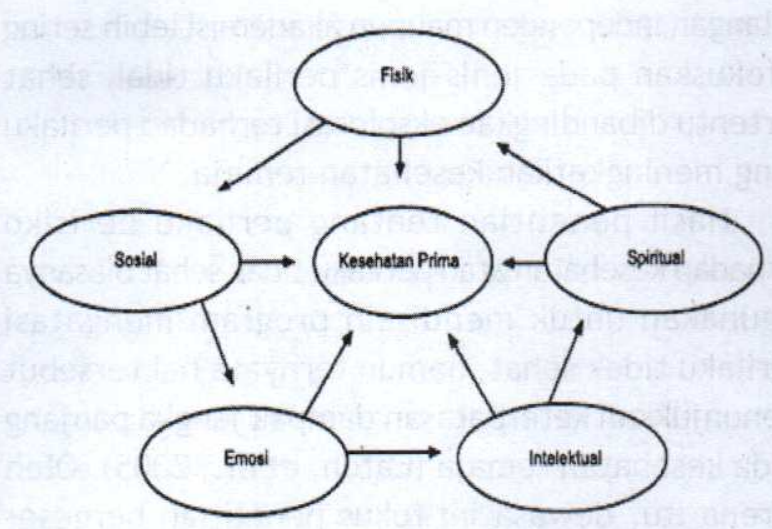

Gambar 1. Dimensi kesehatan prima. Sumber Kozier et al. (1997).

Hendrik L.Blum (Maulana, 2009) menyatakan faktor-faktor yang mempengaruhi kesehatan individu berdasarkan besarnya pengaruh secara berurutan, meliputi faktor lingkungan, faktor perilaku kesehatan, pelayanan kesehatan, dan faktor keturunan yang saling mempengaruhi satu sama lain. Status kesehatan akan optimal jika keempat dimensi tersebut secara bersama-sama berada dalam kondisi optimal. Jika satu faktor terganggu (tidak optimal), status kesehatan juga cenderung akan tidak optimal. Dengan kata lain, intervensi terhadap kesehatan seharusnya ditujukan pada keempat faktor tersebut.

Perilaku sehat didefinisikan oleh Alons (Weiss \& Lonnquest, 1997) sebagai aktivitas yang dilakukan oleh individu maupun kelompok yang dimaksudkan untuk menghindarkan diri dari persoalan kesehatan. Salah satu bagian dari perilaku sehat adalah perilaku preventif, yakni perilaku yang dimaksudkan untuk meminimalkan risiko atau kemungkinan terjadinya penyakit, kecelakaan dan kecacatan. Dalam kelompok ini tercakup berbagai ragam perilaku yang bersifat larangan (perilaku tidak merokok, tidak teradiksi alkohol, tidak melakukan seks bebas) maupun perilaku yang bersifat dorongan (pola makan sehat, berolahraga). Kasl dan Cube (Sarafino, 1990) memperluas definisi perilaku sehat dengan menambahkan perilaku mendeteksi penyakit di dalam tahap sebelum munculnya penyakit. Istilah ini dikenal dengan perilaku terkait kesehatan atau health related behavior. Istilah ini dapat merangkum perilaku risiko, yakni perilaku yang merugikan kesehatan maupun perilaku yang meningkatkan kesehatan yang mengarah pada perilaku-perilaku preventif.

Kulbok dan Kox (2002) mendefinisikan perilaku sehat sebagai perilaku individu terlibat dalam aktifitas yang menjaga dan meningkatkan kesehatannya. 
Perilaku yang meningkatkan kesehatan secara komprehensif mencakup kegiatan seperti olahraga teratur, diet seimbang, mengambil tindakan pencegahan keselamatan, dan tidur yang cukup, (Kohl, Fulton, \& Caspersen, 2000; Murphey et al., 2004; Stanton, Willis, \& Balanda, 2000 dalam Shaffer-Hudskin, 2011). Perilaku sehat yang paling umum dilakukan oleh remaja didasarkan pada hasil review Spear dan Kulbok (2001) pada 34 studi perilaku sehat remaja yang dipublikasikan antara tahun 1984 dan 1994 meliputi perilaku makan bernutrisi, olahraga, kebiasaan yang higienis, pola tidur yang baik, tidak mengkonsumsi zat terlarang dan berbahaya zat (alkohol, obat, dan rokok), menghindari perilaku seksual bebas dan kontrasepsi, serta pemakaian sabuk pengaman saat mengemudi.

Konsep perilaku sehat multidimensi dikembangkan oleh Pender et al. (2005) yang dikenal dengan penyebutan perilaku yang meningkatkan kesehatan atau perilaku promosi kesehatan. Dalam definisi ini perilaku sehat tidak hanya dikaitkan dengan perilaku dimaksudkan untuk meningkatkan kesehatan fisik tetapi juga kesejahteraan individu. Perilaku promosi kesehatan yang dikonseptualisasikan oleh Pender et al. (2005) didefinisikan sebagai perilaku yang meningkatkan kesejahteraan dan potensi kesehatan individu. Perilaku promosi kesehatan adalah kegiatan yang menjadi bagian dari gaya hidup dan ditujukan untuk memelihara status kesehatan individu saat ini atau bergerak menuju level status kesehatan yang lebih tinggi. Pender menggambarkan gaya hidup sehat sebagai gabungkan komponen perilaku protektif (pencegahan) dan perilaku promotif kesehatan. Pender membedakan fokus masing-masing komponen ke dua perilaku tersebut, dimana perilaku proteksi diarahkan pada mengurangi resiko kesehatan dengan menurunkan kemungkinan individu mengalami penyakit atau cedera, sedangkan perilaku promosi kesehatan meliputi pendekatan positif terhadap hidup, di mana kegiatan yang dilakukan individu langsung ditujukan untuk mempertahankan, meningkatkan kesejahteraan seseorang dan aktualisasi potensi kesehatan diri individu (Pender, et al., 2005). Menurut Pender perilaku promosi kesehatan meliputi beberapa dimensi; yakni : perilaku yang bertanggungjawab terhadap kesehatan meliputi tindakan atau perilaku seseorang yang meningkatkan kesehatan; aktifitas fisik (olahraga) yang teratur dan cukup; perilaku makan bernutrisi; penghargaan terhadap hidup, hubungan interpersonal dan manajemen stres meliputi upaya yang dilakukan untuk mengatasi, mengendalikan dan mengelola stres agar tidak mengganggu kesehatan baik fisik maupun psikis.

Pada masa remaja, kebiasaan berperilaku sehat merupakan hal yang fundamental bagi perkembangan yang sehat, misalnya perilaku olah raga, diet seimbang, mengambil tindakan pencegahan keselamatan, dan tidur yang cukup (Mullan Harris et al., 2005). Para peneliti menekankan perlunya mempromosikan kebiasaan sehat pada remaja karena pada masa ini terutama pada remaja awal merupakan periode inisiasi atau awal mula remaja merumuskan sendiri kebiasaan berperilaku sehat yang akan berlanjut menjadi kebiasaan di usia selanjutnya (Danner, 2000). Dengan demikian, fokus mempromosikan kebiasaan yang sehat pada usia remaja menjadi hal yang penting karena dapat berefek jangka panjang terhadap kesehatan fisik maupun mental mereka ( Youngblade \& Curry, 2006).

Berdasarkan paparan di atas dapat disimpulkan beberapa hal sebagai berikut :

1) Sehat merupakan suatu keadaan yang sempurna baik secara fisik, mental dan sosial, serta terbebas dari penyakit, cacat dan kelemahan.

2) Faktor-faktor yang mempengaruhi kesehatan individu meliputi faktor lingkungan, faktor perilaku kesehatan, pelayanan kesehatan, dan faktor keturunan yang saling mempengaruhi satu sama lain.

3) Perilaku promosi kesehatan didefinisikan sebagai kegiatan/aktivitas yang dilakukan oleh individu untuk meningkatkan status kesejahteraan dan kesehatannya, yang meliputi enam dimensi, yakni perilaku mencari dukungan sosial, perilaku yang bertanggung jawab terhadap kesehatan, penghargaan pada kehidupan, managemen emosi, perilaku nutrisi, dan perilaku berolahraga.

\section{Faktor-Faktor Yang Mempengaruhi Perilaku Kesehatan}

Sakdiyah (2011) telah mereview beberapa hasil-hasil yang penelitian telah mengidentifikasi faktor-faktor yang memengaruhi perilaku sehat remaja, antara lain:

1) Harga diri. Berdasarkan hasil-hasil penelitian tentang perilaku sehat remaja harga diri terbukti merupakan variabel kepribadian penting yang menjadi determinan perilaku sehat. Hal ini dibuktikan dalam studi metaanalisis determinan perilaku sehat yang dilakukan oleh (Eftekhari, et al., 2004; Kawabata, et al., (1999); Sakdiyah, (2011); Suryosaputro et al. (2006); Yarcheski 
et al. (2004), Young et al., (1989). Remaja dengan harga diri rendah lebih cenderung mengadopsi perilaku-perilaku penuh risiko dibandingkan remaja dengan harga diri yang tinggi.

2) Strategi Koping. Strategi koping sebagai variabel prediktif perilaku sehat dibuktikan dalam beberapa hasil penelitian. Penelitian BenZur., et al. (2001) menemukan strategi koping berfokus emosi secara positif terkait dengan berbagai negative outcomes kesehatan, seperti depresi (Ben-Zur, et al., 2001), kecemasan (Cosway et al., 2000), progres penyakit yang semakin cepat, lemahnya tingkat kesembuhan penyakit (Drossman et al., 2000), perilaku merokok (Maulin, 2012; Sakdiyah, 2011), dan mengkonsumsi minuman beralkohol (Sakdiyah, 2011). Koping meliputi strategi kognitif dan perilaku dimana individu menggunakan keduanya untuk mengatur situasi yang menekan dan reaksi-reaksi negatif yang ditimbulkannya. Rendahnya kemampuan koping mengarah pada tindakan-tindakan agresif impulsif dan tak terencana selama waktu-waktu emosi berada dalam keadaan tinggi. Rendahnya kemampuan koping yang berfokus pada problem (problem focus coping) tidak hanya berhubungan dengan arah perilaku, tetapi juga mempengaruhi beberapa mekanisme yang dapat memengaruhi perkembangan perilaku tidak sehat dan conduct problem (Frick \& Kochanska, dalam Mowder, 2008)

3) Persepsi lebih tua dari teman sebaya. Penelitian Resnick, et al., (1997, dalam Williams, et al., 2002); Brooks-Gunn \& Petersen, (1993, dalam Williams, et al., 2002) menemukan bahwa persepsi lebih tua daripada teman sebaya berhubungan dengan keterlibatan remaja terhadap perilaku tidak sehat seperti, merokok, mengkonsumsi alkohol, penggunaan marijuana, serta prakarsa dini aktivitas seksual. Merasa lebih tua dari teman sebaya secara luas berdampak pada ketidakmampuan beradaptasi remaja yang pada akhirnya dihubungkan dengan prakarsa perilaku yang berisiko terhadap kesehatan.

4) Perkembangan kognitif. Perkembangan kognitif juga dianggap memengaruhi keterlibatan remaja pada perilaku yang berisiko terhadap kesehatan. Pada penelitian Holmbeck, dkk. (Williams, et al., 2002) yang menguji korelasi kognitif, sikap, dengan perilaku kontraseptif remaja, serta penelitian tentang persepsi risiko remaja diketahui bahwa keputusan remaja terlibat dalam perilaku berisiko dipengaruhi oleh keterbatasan kognitif remaja dan juga sistem nilai remaja yang bersangkutan.

5) Hubungan interpersonal. Berkenaan dengan konteks interpersonal, kelekatan dengan orang tua (seperti perasaan hangat, cinta, perhatian) dan tingkat ekspektasi orang tua pada remaja untuk menyelesaikan sekolah merupakan prediktor penting dari beberapa perilaku berisiko (seperti penggunaan alkohol, tembakau, dan marijuana dan aktivitas seksual dini (Resnick, et al., 1997 dalam Williams, et al., 2002). Kualitas kelekatan berhubungan dengan banyak aspek psikososial remaja. Dalam penelitian Allen, Moore, Kupermine, dan Bell, (1998, dalam Williams, et al., 2002) ditemukan bahwa kelekatan aman diasosiasikan dengan tingkat kompetensi remaja dalam berinteraksi dengan kawan sebaya, level perilaku internal yang lebih rendah, dan level perilaku menyimpang yang lebih rendah. Kelekatan yang aman dengan orang tua mempengaruhi perilaku remaja dalam meningkatkan kesehatan melalui berbagai cara, meliputi, cara penyesuaian diri remaja, kompetensi akademik, dan afiliasi yang rendah dengan teman sebaya yang menyimpang (Bogenschneider, Wu, Raffaelli, \& Tsay, 1998; Gerrard, Gibbons, Zhao, Russell, \& Reis-Bergan, 1999 dalam Williams, et al., 2002) dan harga diri yang tinggi (Sakdiyah, 2010).

6) Hubungan dengan sekolah. Hubungan dengan sekolah juga ditemukan menjadi faktor protektif perilaku berisiko. Kesulitan akademik dan komitmen sekolah yang rendah bersifat prediktif terhadap tingkat perilaku berisiko remaja (Bailey \& Hubbard; Elliot, 1990; Huizinga, \& Ageton, 1985; Jessor \& Jessor, 1997; Jessor, et al., 1995, Resnick, et al., 1997, dalam Williams, et al., 2002).

7) Status sosial-ekonomi dan gender. Dalam studi metaanalisis Yarcheski, et al. (2004), penelitian Suryosaputro dkk., (2006), penelitian Huure et al., (2005) dan Leganger \& Kraft, (2003) status sosial ekonomi menjadi faktor prediktif perilaku sehat remaja. Remaja dengan tingkat pendidikan yang lebih tinggi dan memiliki orang tua yang berstatus sosial ekonomi tinggi memiliki kecenderungan berperilaku sehat yang lebih tinggi. Demikian pula dengan perbedaan jenis kelamin yang ditemukan menjadi prediktor perilaku sehat, 
dimana perilaku merokok dan mengkonsumsi alkohol dan narkoba lebih banyak ditemukan pada remaja laki-laki dibandingkan remaja perempuan (Yarcheski, et al. (2004).

8) Loneliness. Studi metaanalisis loneliness juga terbukti memiliki pengaruh negatif yang kuat pada praktek perilaku sehat yang positif (Yarcheski, et al., 2004). Penelitian Peplau \& Perlman ( Yarcheski et al., 2004) juga menemukan individu dengan loneliness tinggi yang digambarkan sebagai individu apatis dan tanpa memiliki tujuan, tidak memiliki energi untuk menyelesaikan tugas dengan sukses adalah populasi yang rentan terhadap praktik perilaku tidak sehat

\section{HIPOTESA PENELITIAN}

Ada perbedaan dimensi perilaku mempromosikan kesehatan remaja berdasarkan jenis kelamin.

\section{METODE PENELITIAN}

Variabel Penelitian

Variabel dalam penelitian ini adalah perilaku promosi kesehatan dan jenis kelamin :

\section{Perilaku promosi kesehatan}

Perilaku promosi kesehatan adalah perilaku yang meningkatkan status kesejahteraan dan kesehatan individu yang dilakukan dengan cara : melakukan perilaku yang bertanggungjawab terhadap kesehatan; beraktifitas fisik (olahraga) yang teratur dan cukup; memakan makanan yang bernutrisi; mengembangkan dukungan sosial, menghargai hidup dan mengelola stres. Perilaku promosi kesehatan yang tinggi ditunjukkan oleh skor yang tinggi dalam skala perilaku promosi kesehatan, yang berarti individu mampu mempertahankan dan meningkatkan kesehatannya.

\section{Jenis Kelamin.}

Jenis kelamin dalam penelitian ini adalah laki-laki dan perempuan

Subjek Penelitian

Subyek dalam penelitian ini berjumlah 214 orang, berusia 15 hingga 18 tahun. Subjek penelitian dari SMAKN 2 dan SMAN 4 Malang yang diambil dengan menggunakan teknik random cluster sampling.

\section{Instrumen Pengukuran}

Perilaku promosi kesehatan diukur dengan menggunakan skala perilaku promosi kesehatan yang diadaptasi dari Adolescent Health Profile
(AHP) Chen, dkk., (2003) yang dikembangkan dengan mengacu pada kerangka teori perilaku promosi kesehatan Pender, dkk (2005). Terdiri dari 40 item yang mengukur enam dimensi perilaku promosi kesehatan, yakni: nutrisi, dukungan sosial, penghargaan terhadap hidup, tanggung jawab kesehatan, manajemen stres, dan perilaku olahraga. Setiap responden diminta untuk menunjukkan seberapa sering mereka melakukan setiap jenis perilaku promosi kesehatan. Menggunakan 5 respon jawaban, item-item dalam setiap kategori dikode dengan nilai 1 (tidak pernah) hingga 5 (selalu). AHP telah melewati uji validitas isi oleh panel ahli medis dan psikologis profesional. Setelah itu dilakukan uji daya beda aitem, yang menunjukkan terdapat 31 aitem yang memiliki koefisien daya beda diatas 0,3 , dan 9 aitem memiliki koefisen daya beda dibawah 0,3 . Rentang koefisien daya beda antara 0,301 0,506 , yang menghasilkan reliabilitas konsistensi internal sebesar 0,861

\section{Analisa Data}

Sesuai dengan tujuan penelitian ini yaitu untuk mengetahui perbedaan perilaku mempromosikan kesehatan berdasarkan jenis kelamin, maka dilakukan uji t dibantu dengan program SPSS 17.00 for windows.

\section{HASIL \& PEMBAHASAN \\ Uji Deskripsi}

Berdasarkan uji deskripsi ditemukan dari total 214 subjek penelitian yang menunjukkan perilaku sehat promotif kategori sedang sebanyak 104 orang (48.6\%), dan kategori tinggi sebanyak 110 orang (48.6\%). Secara umum tidak ada subjek penelitian yang menunjukkan perilaku sehat promotif dalam kategori rendah.

Analisis prosentase tentang tiap-tiap dimensi perilaku kesehatan promotif remaja menunjukkan dari total 214 subjek penelitian yang memiliki dukungan sosial kategori sedang ada 74 orang (34.6\%), yang memiliki dukungan sosial tinggi ada 140 orang (65.4\%), dan tidak ada yang memiliki dukungan sosial rendah. Subjek penelitian yang memiliki penghargaan hidup kategori sedang ada 41 orang (19.2\%), kategori tinggi sebanyak 173 orang $(80.8 \%)$, dan tidak ada yang memiliki penghargaan terhadap hidup dalam kategori rendah. Subjek penelitian yang menjalani perilaku hidup yang bertanggung jawab pada kesehatan pada kategori rendah sebanyak 8 orang $(3.7 \%)$, yang menjalani perilaku hidup yang bertanggung jawab pada kesehatan pada 
kategori sedang yakni ada 153 orang (71.5) dan yang menjalani perilaku hidup yang bertanggung jawab pada kesehatan pada kategori tinggi ada 53 orang $(24.8 \%)$. Subjek penelitian yang memiliki menegemen stres pada kategori rendah sebanyak 4 orang $(1.9 \%)$, yang memiliki managemen stres pada kategori sedang yakni ada 134 orang (62.6\%) dan yang memiliki menegemen stres pada kategori tinggi ada 76 orang $(35.5 \%)$.

Subjek penelitian yang menjalani pola makan sehat (bernutrisi) kategori rendah sebanyak 4 orang (1.9\%), kategori sedang yakni sebanyak 133 orang (62.1\%) dan yang berada pada kategori tinggi ada 77 orang (36\%). Subjek penelitian yang melakukan olahraga pada kategori rendah sebanyak 13 orang (6.1\%), kategori sedang sebanyak 148 orang (69.2) dan pada kategori tinggi ada 53 orang (24.8\%).

\section{Pembahasan}

Berbeda dengan prediksi peneliti tidak semua dimensi perilaku mempromosikan kesehatan berbeda antara laki-laki dan perempuan. Hanya dua dimensi yang berbeda yakni perilaku nutrisi dan perilaku olahraga, dimana remaja laki-laki menunjukkan tingkat yang lebih tinggi dibandingkan remaja perempuan.

Hasil penelitian ini hampir sama dengan hasil penelitian tentang dimensi perilaku sehat promotif yang dilakukan oleh Spears dan Kulbok (2001) menemukan bahwa gender adalah faktor utama yang berhubungan dengan tingkat perilaku kesehatan promotif remaja. Beberapa penelitian yang mengkaji tema ini juga menemukan bahwa remaja putri lebih mungkin untuk berlatih beberapa perilaku promotif kesehatan (yaitu, kebiasaan diet, perawatan, dan masalah keamanan) daripada lakilaki, dengan pengecualian aktivitas fisik, dimana laki-laki lebih mungkin untuk terlibat di dalamnya (Saffer-Hudskin, 2010). Namun, berbeda dengan hasil penelitian tersebut, penelitian ini menemukan remaja putri menunjukkan perilaku nutrisi yang lebih rendah dibandingkan remaja putra.

Pada penelitian dengan skala yang lebih besar tentang dua perilaku promotif yakni perilaku nutrisi dan aktivitas fisik, perbedaan gender telah dibuktikan berpengaruh dominan pada perilaku sehat dibandingkan variabel yang lain. Munoz, Krebs-Smith, Ballard-Barbash, dan Cleveland (1997, dalam Saffer-Hudskin, 2010) meneliti asupan makanan pada sampel 3.307 anak-anak dan remaja, menemukan bahwa remaja laki-laki memenuhi tingkat minimal makanan yang direkomendasikan pada tiga kelompok makanan (biji-bijian, sayuran, dan daging), sedangkan remaja putri tidak memenuhinya. Hasil ini menunjukkan kebiasaan nutrisi lebih sehat untuk laki-laki dibanding remaja putrid. Namun, temuan dari Survei Kesehatan Remaja Minnesota (MAHS) menunjukkan bahwa sebagian besar anak laki-laki vs perempuan ( $65 \%$ vs $48 \%$, masing-masing) memiliki asupan makanan sehari-hari terdiri dari $30 \%$ atau\% lebih banyak lemak dan 10 atau lemak jenuh lebih (Neumark-Sztainer, Story, Hannan, \& Croll, 2002).

Para peneliti memberikan hipotesis bahwa perbedaan ini mungkin dikaitkan dengan asupan kelompok makanan yang berbeda dari anak lakilaki dan perempuan. Perbedaan jenis kelamin juga dilaporkan pada jumlah aktivitas fisik yang dilakukan remaja sekolah menengah. Laki-laki dilaporkan lebih sering terlibat dalam interaksi olahraga tim seperti sepak bola dan basket sementara perempuan cenderung terlibat pada jenis kegiatan berenang, bersepeda, dan menari (Pate, panjang, \& Heath, 1994). Sebuah studi yang lebih baru oleh sekelompok peneliti melaporkan bahwa laki-laki lebih mungkin untuk berpartisipasi dalam tim olahraga di sekolah tinggi (Pate, Trost, Levin, \& Dowda, 2000). Temuan di penelitian tingkat nasional juga mencatat aktivitas laki-laki, antara lain partisipasi dalam program olahraga, keterlibatan dalam tim olahraga, dan kegiatan waktu senggang menunjukkan tingkat yang lebih tinggai secara signifikan (Dowda, Ainsworth, Addy, Saunders, \& Riner, 2001; Pate et al, 2000). Data dari YRBSS terbaru (Hudskin, 2011) menunjukkan bahwa hampir dua kali lipat persentase remaja laki-laki $(43,7 \%)$ dibandingkan remaja perempuan $(25,6 \%)$ yang memenuhi tingkat aktivitas fisik dalam satu minggu yang yang direkomendasikan (yaitu, segala macam aktivitas fisik yang meningkatkan jantung dan pernapasan selama 6 menit per hari dan 5 hari per minggu).

Perbedaan pola makan sehat (bernutrisi ) pada remaja laki-laki dan perempuan di Indonesia dapat dijelaskan berdasarkan beberapa alasan berikut, yakni: Pertama, kebiasaan makan yang buruk remaja putri. Kebiasaan makan biasanya berpangkal pada kebiasaan makan keluarga yang juga tidak baik, yang telahh tertanam sejak kecil akan terus terjadi pada usia remaja. Mereka makan seadanya tanpa mengetahui kebutuhan akan berbagai zat gizi dan dampak tidak dipenuhinya kebutuhan zat gizi tersebut terhadap kesehatan mereka. Penelitian yang dilakukan oleh Jeong A. Kim di Korea (2001, 
dalam jafar, 2012) menemukan bahwa pola makan pada remaja mempengaruhi status gizi mereka. Penelitian ini mengelompokkan remaja pada tiga pola makan. Pertama, yang disebut dengan pola makan tradisional Korea, merupakan pola makan yang banyak mengkonsumsi Kimchi dan nasi, ikan dan rumput laut. Kedua, yang disebut pola makan barat, merupakan pola makan yang banyak mengkonsumsi tepung dan roti, hamburger, pizza, makanan ringan dan sereal, gula dan makanan manis. Ketiga, yang disebut pola makan modifikasi, merupakan pola makan yang banyak mengkonsumsi mie, tetapi diselingi dengan kimchi dan nasi. Ditemukan kejadian obesitas sentral paling tinggi pada pola makan barat $(16,8 \%)$ dari pada pola makan tradisional Korea $(9,76 \%)$ dan pola makan modifikasi $(9,75 \%)$.

Kedua, sarapan pagi. Lena Hamstrong menemukan bahwa di Eropa sekitar 34\% remaja melewatkan sarapan di pagi hari. Dan kebiasaan sarapan pada remaja dipengaruhi oleh kebiasaan orang tua mereka (dalam Jafar, 2012). Ditemukan pula bahwa remaja yang memiliki kebiasaan sarapan memiliki kecendrungan untuk tidak mengalami obesitas. Ketiga, pemahaman gizi yang keliru. Tubuh yang langsing sering menjadi idaman bagi para remaja terutama remaja puteri. Hal itu sering menjadi penyebab masalah, karena untuk memelihara kelangsingan tubuh mereka menerapkan pengaturan pembatasan makanan secara keliru .Sehingga kebutuhan gizi mereka tak terpenuhi. Hanya makan sekali sehari atau makan makanan seadanya, tidak makan nasi merupakan penerapan prinsip pemeliharaan gizi yang keliru dan mendorong terjadinya gangguan gizi. Penelitian yang dilakukan oleh Ruka Sakamaki, dkk (2004, dalam Jafar 2012) menemukan bahwa pelajar wanita di China memiliki keinginan yang besar untuk menjadi langsing $(62,0 \%)$ dibandingkan dengan pelajar lelaki $(47,4 \%)$. Demikian pula dengan studi sebelumnya yang dilakukan di Jepang, perubahan gaya hidup telah menyebabkan sebagian besar pelajar wanita memiliki keinginan untuk menjadi langsing, meskipun jumlah responden yang mengalami obesitas sangat sedikit pada studi tersebut. Di tahun 2005, penelitian mereka berlanjut dan menemukan bahwa sebagian besar responden yang memiliki IMT normal, ternyata menginginkan ukuran tubuh dengan IMT yang tergolong kurus (BMI : 18,4+3,4).

Ketiga, kesukaan yang berlebihan terhadap makanan tertentu. Kesukaan yang berlebihan terhadap makanan tertentu saja menyebabkan kebutuhan gizi tak terpenuhi. Keadaan seperti itu biasanya terkait dengan "mode" yang tengah marak dikalangan remaja, misalnya remaja-remaja putri sangat menggandrungi makanan kaki lima yang belum jelas aspek keamanannya terhadap kesehatan tubuh, misalnya cilok, cireng, bakso dan lain-lain. Keempat, promosi yang berlebihan melalui media massa. Usia remaja merupakan usia dimana mereka sangat tertarik pada hal-hal baru. Kondisi tersebut dimanfaatkan oleh pengusaha makanan untuk mempromosikan produk mereka dengan cara yang sangat mempengaruhi remaja. Padahal, produk makanan tersebut bukanlah makanan yang sehat bila dikonsumsi dalam jumlah yang berlebihan.

Kelima, masuknya produk-produk makanan baru yang berasal dari negara lain secara bebas mempengaruhi kebiasaan makan para remaja. Jenis-jenis makanan siap santap (fast food) yang berasal dari negara barat seperti hot dog, pizza, hamburger, fried chicken dan french fries, berbagai jenis makanan berupa kripik (junk food) sering dianggap sebagai lambang kehidupan modern oleh para remaja. Padahal berbagai jenis fast food itu mengandung kadar lemak jenuh dan kolesterol yang tinggi disamping kadar garam. Zat-zat gizi itu memicu terjadinya berbagai penyakit kardiovaskuler pada usia muda. Penelitian yang dilakukan oleh Kerry N. Boutelle, at al (2005) menemukan bahwa konsumsi fast food berhubungan dengan berat badan orang dewasa namun tidak pada remaja. Hal tersebut disebabkan karena remaja membutuhkan banyak kalori untuk aktivitasnya, sehingga fast food tidak mempengaruhi status gizi mereka untuk menjadi obesitas. Namun, konsumsi fast food bisa meningkatkan risiko bagi para remaja untuk menjadi obes pada saat dewasa kelak (dalam Jafar, 2012).

Beberapa hal tersebut di atas menjadi pemrediksi mengapa remaja putri menunjukkan kecenderungan perilaku nutrisi yang lebih rendah dibandingkan remaja putra.

\section{SARAN}

Berdasarkan temuan penelitian, maka terdapat beberapa saran yang bisa dipertimbangkan bagi semua pihak yang terlibat dengan dunia remaja untuk semakin mengembangkan kebiasaan perilaku sehat remaja :

1. Pentingnya diadakan sosialisasi terutama pada remaja putri tentang pola makan sehat, jenis makanan sehat dan tidak sehat serta dampak dari makanan tersebut pada pada kesehatan

2. Bagi pihak sekolah sedapat mungkin mensterilkan 
lingkungan sekolah dari jenis makanan tidak sehat untuk membatasi akses siswa pada makanan tidak sehat di sekolah

3. Bagi pihak sekolah, sedapat mungkin menyediakan secara berimbang fasilitas olahraga bagi remaja, putra maupun putri, karena terdapat perbedaan keterlibatan remaja berdasar jenis kelamin pada jenis-jenis olahraga tertentu,

\section{DAFTAR PUSTAKA}

Chasanah. M.A., (2010). Hubungan antara gaya hidup sehat dengan perilaku merokok pada karyawan di Yogyakarta. Skripsi. Tidak diterbitkan. UMS

Diener, E. (2000). Subjective well-being: The science of happiness and a proposal for a national index. American Psychologist, 55, 34-43.

Eaton, D.K., Kann, L., Kinchen, S., Ross, J., Hawkins, J., Harris, W.A., et al. (2005). Youth Risk Behavior Surveillance. Surveillance Summaries, 55-65

Edelman, CL and Mandle, CL (1994). Health promotion throughout the lifespan (3rd ed.). Missouri: Mosby Year Book, Inc

Ford, N., Siregar, K., Ngatimin, R., and Maidin, A. (1997). The Hidden Dimension: Sexuality and Responding to the Threat of HIVIAIDS in South Sulawesi, Indonesia. Health And Place ; 3: 249-358.

Hasmi E. (2001). Meeting Reproductive Health Needs of Adolescent in Indonesia. J of Adolescent Reproductive and Sexual Health UNESCO. http://www.unescobkk.org/ips/arh.

Hatmadji SH, Rochani S. (1993). Adolescent Reproductive Health in Indonesia. Research Report of Joint Cooperation. Jakarta: Demographic Institute Faculty of Economic University of Indonesia, The Ford Foundation, RAND Corporation, The World Health Organization, Yayasan Kusuma Buana

Hendricks, D.L., \& Hendricks, C.S., (2005)The Relationship of Hope and Self-Efficacy to Health Promoting Behaviors Among Student- misal: remaja putri lebih cenderung memilih olahraga berenang, menari, aerobic, dll, sedang remaja putra lebih tertarik dengan sepakbola, basket, dan permainan olahraga tim lainnya, sedangkan selama ini fasilitas olahraga yang disediakan oleh pihak sekolah lebih banyak mengarah kepada jenis olahraga remaja putra.

Athletes Attending Historically Black College \& Universities, Journal of Multicultural Nursing \& Health; 11, 3; ProQuest Research Library pg. 23

Jafar, Nurhaedar (2012) Perilaku gizi seimbang pada remaja. Handout. Tidak dipubikasikan. Program studi Ilmu Gizi. Fakultas Ilmu Kesehatan Masyarakat. Universitas Hasanudin

Keyes, C.L.M. (2005). Mental illness and/or mental health: investigating axioms of the complete state model of health. Journal of Counseling and Clinical Psychology, 73 (3), 539-548

Kulbok, P.A. \& Cox, C.L. (2002). Dimensions of adolescent health behavior. Journal of Adolescent Health, 31, 394-400.

Kozier, Erb \& Blais. (1997). Profesional nursing practice : concept \& perspectives. Third Edition. California : Addison Wesley Publishing.Inc

Maulana, H.D.J. (2009) Promosi Kesehatan. Buku Kedokteran EGC. Jakarta

Pender, N. J., Murdaugh, C. L., \& Parsons, M. A. (2002). Health promotion in nursingpractice (4th ed.). Upper Saddle River, NJ: Prentice Hall

PKPBI (2005) Sex Pranikah Remaja di Medan, Yogya, Surabaya, Kupang. Laporan Penelitian, Jakarta, PKPBI

Potter, P. \& Perry A.G., (2005) Buku Ajar Fundamental Keperawatan : konsep, proses, dan praktek, Alih Bahasa, Yasmin Asih et al. Editor edisi Bahasa indonesia, Devi Yulianti, Monica Ester. Ed.4. - Jakarta

Sarafino, E.P. (1990). Health Psychology, Biopsychosocial Interactions. New York: John Willey and Son 
Shaffer-Hudkins, E.J. (2011) Health Promoting Behavior and Subjective Well-Being Among Early Adolescents. Thesis and Dissertation On Line. (diakses dari http://scholarcommons.usf.edu/ etd/3341) $\left(6^{\text {th }}\right.$ ed). Belmont, Wodsworth. CA

Spear, H.J. \& Kulbok, P.A. (2001). Adolescent health behaviors and related factors: A review. Public Health Nursing, 18 (2), 82-93.

Suryoputro A., Ford, J.N., Shahuliyah (2006) Faktorfaktor yang mempengaruhi perilaku seksual remaja di Jateng: Implikasinya terhadap kebijakan \& layanan kesehatan seksual \&reproduksi, Makara Kesehatan, Vol. 10, no 1

Syam, Sunarti (2011). Perilaku Gizi Seimbang Mahasiswa Sekolah Tinggi Ilmu Kesehatan STIK Makassar. Skripsi Tidak diterbitkan. Makassar
Synovate Research (2005) Perilaku Seksual Kawula Muda di Empat Kota Besar (Jakarta, Bandung, Surabaya, Medan) Laporan Penelitian , Jakarta, Synovate Research \& DKT Indonesia

Widianti, E., (2007) Remaja dan Permasalahannya: Bahaya Merokok, Penyimpangan Seks Pada Remaja, Dan Bahaya Penyalahgunaan Minuman Keras/Narkoba, Makalah, Disampaikan dalam penyuluhan sosial mengenai remaja dan permasalahannya. Fakultas Ilmu Keperawatan Universitas Padjajaran

Youngblade, L.M. \& Curry, L.A. (2006). The people they know: Links between interpersonal contexts and adolescent risky and health-promoting behavior. Applied Developmental Science, 10 (2), 96-106. 